\title{
Correlation of Work Period and Age with the Compliance with the Use of Ear Protection Equipment on Production Workers in an East Java Animal Feed Industry
}

\author{
Hubungan Masa Kerja dan Umur dengan Kepatuhan Menggunakan Alat \\ Pelindung Telinga pada Pekerja Produksi di Industri Pakan Ternak Jawa Timur
}

\author{
Fatma Nuriyanti Mochtar ${ }^{1}$, Zikri Fathur Rahman ${ }^{1}$, Y. Denny Ardyanto Wahyudiono ${ }^{2}$ \\ ${ }^{1}$ Magister of Occupational Health and Safety, Faculty of Public Health, Universitas Airlangga \\ ${ }^{2}$ Department of Occupational Safety and Health, Faculty of Public Health, Universitas Airlangga \\ Campus C Mulyorejo, Surabaya, East Java, 60115 Indonesia
}

\begin{abstract}
Introduction: Ear protection equipment is indispensable for workers exposed to noise exceeding the threshold value. Many studies have shown that the level of labor compliance with the use of ear protection equipment is influenced by the length of work and age of the workers concerned. However, many studies also show different conditions with the results of these studies. For this reason, this study was conducted to determine how the influence of the work period and age of workers on the compliance with the use of ear protection equipment at PT X animal feed industry. Methods: The method used was observational with a cross-sectional approach. The number of population selected from animal feed production workers was 30 workers. The sample was obtained using a simple random sampling calculation of 28 workers. The analysis was done using contingency coefficient statistical tests. Results: The number of workers in the study area whose tenure $<12$ years is $50 \%$ and whose age $<37$ years is was also $50 \%$. By using the contingency coefficient, it is known that there are $39.3 \%$ and $35.7 \%$ of $64.3 \%$ of workers who were not compliant with the useof ear protection equipment, each having a work period of $<12$ years and age $<37$ years respectively. It is also known that work period and age of workers have a $\operatorname{Sig}(0.115)>\alpha(0.05)$ and $\operatorname{Sig}(0.430)>\alpha(0.05)$ accordingly, which means there is no relationship between work period and the age of the workers with the compliance with the use of ear protection equipment. Conclusion: The reasons of the non-compliance of workers with the use of ear protection equipment are they feel uncomfortable, they have a lack of supervision, as well as they have a lack of motivation work.
\end{abstract}

Keywords: age, animal feed, compliance, ear protection equipment, years of service

\section{ABSTRAK}

Pendahuluan: Alat pelindung telinga (APT) sangat diperlukan bagi pekerja yang terpapar kebisingan melebihi nilai ambang batas. Banyak penelitian membuktikan bahwa tingkat kepatuhan pekerja memakai APT dipengaruhi oleh masa kerja dan umur pekerja yang bersangkutan. Hanya saja, banyak juga penelitian menunjukkan kondisi berbeda dengan hasil penelitian tersebut. Untuk itu, penelitian ini dilakukan guna mengetahui bagaimana pengaruh masa kerja dan umur pekerja terhadap kepatuhan dalam memakai APT di tempat industri pakan ternak PT X. Metode: Metode yang digunakan adalah observational dengan pendekatan crossectional. Populasi yang dipilih dari pekerja-produksi pakan ternak sebanyak 30 pekerja. Sampel didapatkan dengan menggunakan perhitungan simple random sampling yang berjumlah 28 pekerja. Analisisnya dilakukan dengan menggunakan uji statistik coefficient contingency. Hasil: Jumlah pekerja di tempat penelitian yang masa kerjanya $<12$ tahun sebanyak $50 \%$ dan pekerja yang umurnya $<37$ tahun juga $50 \%$. Dengan menggunakan coefficient contingency diketahui bahwa ada $39.3 \%$ dan $35.7 \%$ dari $64.3 \%$ pekerja yang tidak patuh memakai APT, masing-masing memiliki masa kerja $<12$ tahun dan umur $<37$ tahun. Diketahui juga bahwa masa kerja dan umur pekerja masing-masing memiliki nilai $\operatorname{Sig}(0.115)>\alpha(0.05)$ dan $\operatorname{Sig}(0.430)>\alpha(0.05)$ yang artinya tidak terdapat hubungan antara masa kerja dan umur pekerja dengan kepatuhan menggunakan APT. Simpulan: Alasan pekerja terhadap kepatuhan menggunakan APT adalah mereka merasa ketidaknyamanan, diiringi dengan kurangnya pengawasan, serta kurangnya motivas pekerja dalam malukan pekerjaan.

Kata kunci: alat pelindung telinga, kepatuhan, masa kerja, umur, pakan ternak

Corresponding Author:

Y. Denny Ardyanto W.

Email: denny.ard@gmail.com,

Telephone: +6281231796929

(C2021 IJOSH All right reserved. Open access under CC BY NC-SA license doi: 10.20473/ijosh.v10i1.2021.56-63 Received November 01, 2019, received in revised form March 13, 2021, Accepted March 13, 2021, Published: April 2021 


\section{INTRODUCTION}

PT. $X$ is a company engaged in the animal feed industry, which produces one million metric tons per year. The types of fodder produced are animal feed for poultry (chickens and ducks), pigs, cattle, goats and fish. According to the results of a company report in 2017 the animal feed industry is one of the industries that influence the consumption of livestock products due to the increased contribution of poultry meat by $65 \%$ and of chicken eggs by $70 \%$.

The raw materials used by PT. X in making animal feed is organic dust such as corn, rice, oil (sesame flour, coconut flour, rubber seed flour) and fiber (cotton, cotton), all of which are good sources of protein. The production process in PT. $\mathrm{X}$ includes dumping, weighing, grinding, mixing, and packing. Noise is one of the conditions of an unsafe work environment. According to the regulation of the Minister of Manpower number 5 of 2018 concerning occupational safety and health of the work environment, noise is unwanted noise originating from production process equipment or work equipment, which at a certain level can cause hearing loss (Ministry of Manpower of the Republic of Indonesia, 2018).

According to the OHSA (2002) and Farooqui et al. (2009), companies in controlling noise are required to take measurements of noise exposure periodically, provide appropriate hearing protection for workers, notify workers about the results of environmental measurements, and ensure that measurements are made accurately.

PT. X experiences noise from the grinding machine which produces $87.7 \mathrm{dBA}$ sound or exceeds the specified threshold value. The noise generated from the machine has an impact on the hearing of workers in the production department. Based on the results of MCU (medical checkup) in 2018 it is known that there were 9 out of 28 workers experiencing hearing loss.

According to Tarwaka (2004), the impact of noise on the Treshold Limit Value (TLV) includes damage to the sense of hearing, health problems (increased blood pressure, increased pulse, and increased heart rate), and public reactions such as protests to stop the activities. According to the Regulation of the Minister of Manpower number 5 of 2018 concerning occupational safety and health of the work environment, NAB (threshold value) of noise intensity for the exposure time of for 8 hour workshould be $85 \mathrm{dBA}$, andfor 4 hour work should be $88 \mathrm{dBA}$.

According to Ibrahim, Basri and Hamzah (2016), PT. JAPFA Indonesia needs ear protection equipment to protect workers from the noise that exceeds threshold value. Ear protection equipment usage behavior is very influential in someone's hearing complaint. Controls have been carried out by companies to reduce noise problems that occur, such as giving earplugs or earmuffs to each worker and periodic checking every six months.

According to the Regulation of the Minister of Manpower Number: 08 / Men / VII / 2010 (Ministry of Manpower and Transmigration, 2010) concerning Personal Protective Equipment, PPE is a device that can protect someone whose function is to partially or entirely cover the body to avoid the potential danger of accidents and diseases in the workplace. According to Notoatmodjo (2007), behavior occurs when something is needed to cause a reaction that is called a stimulus. Thus, a specific stimulus will produce an individual behavioral reaction. Meanwhile, according to Azwar (2005), behavior is a picture of various mental conditions such as emotions, desires, motivations, views, behavior, reactions, knowledge, interests, and others.

Based on the preliminary observation of the behavior in this study, most workers do not use earplugs during their work activities although the company has provided earplugs to each worker. At the same time, the company has provided earplugs to each worker. This study was conducted to determine how the influence of the work period and age of workers on the compliance with the use of ear protection equipment at PT X animal feed industry.

\section{METHODS}

This research used an observational method with a cross-sectional approach. The population used was animal feed production workers at PT. X. The research was carried out from August 2019 to the beginning of September 2019. This research has received a certificate of ethical conduct from the Faculty of Dentistry Airlangga University Number: 533 / HRECCFODM / VII / 2019.

In this study, the variables were years of service and age, but there were still other variables discussed in this studyas the differentiators of other studies.

The total population was 30 workers. Samples were obtained using simple random sampling calculations, totaling 28 workers. Data were analyzed 
using statistical coefficient contingency tests. In the characteristics of workers at PT X, all variables were categorized into 2 categories each. Specifically, sanctions and rewards were categorized into poor and good, monitoring variable was categorized into poor and good, SOP variable was categorized into poor and good, and PPE availability variable was categorized into poor and good.

The availability of compliance was measured using questionnaires measuring the knowledge of ear protection equipment and respondents' compliance. Workers' attitudes, punishment and rewards were also measured using questionnaires. Moreover, observations on animal feed workers was conducted for 6 times.

\section{RESULTS}

The production process in PT. $\mathrm{X}$ includes dumping, weighing, grinding, mixing, and packing. According to Martino, Rinawati and Rumita, (2015), the danger contained in the animal feed industry includes noise caused by grinding machines, inhalation of dust, flammable materials, scratches by sharp objects, and injuries due to being pinched by pallets.

Table 1. Frequency Distribution of Workers' Characteristics in PT.X in 2019

\begin{tabular}{|c|c|c|c|}
\hline Variables & Category & Frequency & $\begin{array}{c}\text { Percentage } \\
(\%)\end{array}$ \\
\hline \multirow{2}{*}{ Work Period } & $<12$ years & 14 & 50.0 \\
\hline & $\geq 12$ years & 14 & 50.0 \\
\hline \multirow{3}{*}{$\begin{array}{l}\text { Education } \\
\text { Level }\end{array}$} & $\begin{array}{l}\text { Elementary } \\
\text { School }\end{array}$ & 5 & 17.5 \\
\hline & $\begin{array}{l}\text { Junior } \\
\text { School }\end{array}$ & 5 & 17.5 \\
\hline & $\begin{array}{c}\text { High } \\
\text { School / } \\
\text { Vocational } \\
\text { School }\end{array}$ & 18 & 64.3 \\
\hline \multirow{2}{*}{ Age } & $\begin{array}{c}<37 \text { years } \\
\text { old }\end{array}$ & 14 & 50.0 \\
\hline & $\begin{array}{c}\geq 37 \text { years } \\
\text { old }\end{array}$ & 14 & 50.0 \\
\hline \multirow{2}{*}{ Motivation } & Poor & 11 & 39.2 \\
\hline & Good & 17 & 60.8 \\
\hline \multirow{2}{*}{ Knowledge } & Poor & 21 & 75.0 \\
\hline & Good & 7 & 25.0 \\
\hline \multirow[t]{2}{*}{ Attitude } & Poor & 20 & 71.4 \\
\hline & Good & 8 & 28.6 \\
\hline
\end{tabular}

Based on the observation, it is known that as many as 9 out of 30 people (30\%) of production workers do not wear ear protection equipment when working in the production room, whereas the result of the noise measurement in the production room is $87 \mathrm{dBA}$. This means that production workers are exposed to noise as high as $87 \mathrm{dBA}$ for 8 hours per day.

\section{Workers' Characteristics in PT. X in 2019}

PT.X has a total of 30 workers in the production department. This study took a sample of all animal feed workers in the production department, while the characteristics of the respondents are shown in Table 1.

Based on Table 1, the classification of the working period can be divided into 2 , using the median cut. Based on the results, there is the same average between the work periods of $<12$ years and $>12$ years as much as $50 \%$.

Moreover, the results of the frequency distribution of educational level shows that there are more graduates from high school / vocational school as much as $64.3 \%$. Graduates from high school / vocational school usually have more skills and more knowledge.

Furthermore, in the frequency distribution of the age of production workers in PT.X, there is a similar percentage between people aged $<37$ years old and $>$ 37 years old, standing at $50 \%$ each. The age variable of employees is crucial to see the compliance level in using ear protection equipment because a combination of age workers and compliance level can increase the company productivity.

Based on the results of this study, it can be seen that the majority of workers (17 workers or $60.8 \%$ ) have good motivation. Moreover, based on the results on knowledge, it is shown that at most 21 workers $(75.0 \%)$ have poor knowledge. A lack of knowledge can influence adherent workers in using ear protection equipment. Furthermore, it can be explained that at most, 20 workers $(71.4 \%)$ have poor attitude.

\section{Job Factors of Workers at PT. X of 2019}

Based on the Table 2, sanctions are penalties for workers who do not use ear protection equipment. Meanwhile, rewards are given for the full compliance of using the ear protection equipment. Based on the results of the assessment of sanctions and rewards of respondents, a higher number of 
respondents as many as 16 workers $(57.2 \%)$ explain the company is sufficient in providing sanctions or rewards to workers.

Based on the results of regarding supervision, there is a higher number of workers as many as 19 workers $(67.9 \%)$ who feel that they have already had good supervision. Good supervision can influence the use of ear protection devices.

$\mathrm{SOP}$ is measured using questionnaires seen from the SOP in the company. Based on the results of this study, it can be known that at most 16 workers $(57.1 \%)$ feel that the SOP is good.

The availability of PPE is measured using questionnaires with the respondent's recognition approach. The results of the study show that that there is a higher number of workers as many as 17 workers, $(60.7 \%)$ who feel that the availability of PPE is good.

\section{Research Observation Results on Production Workers at PT.X in 2019}

Table 3 explains that 6 workers are compliant and 22 are not compliant regarding the proper use of ear protection devices, which are installed even after working hours. Thus, it can be seen that the compliance with the use of ear protection devices in companies is still very weak or poor. There are more non-obedient workers with a total number of 22 workers, $(78.57 \%)$.

Table 2. Frequency Characteristics of Workers in PT.X in 2019

\begin{tabular}{lccc}
\hline \multicolumn{1}{c}{ Variables } & Category & Frequency & $\begin{array}{c}\text { Percentage } \\
(\%)\end{array}$ \\
\hline Sanction and & Poor & 12 & 42.8 \\
reward & Good & 16 & 57.2 \\
\hline \multirow{2}{*}{ Monitoring } & Poor & 9 & 32.1 \\
& Good & 19 & 67.9 \\
\hline \multirow{2}{*}{ SOP } & Poor & 12 & 42.9 \\
& Good & 16 & 57.1 \\
Availability & Poor & 11 & 39.3 \\
of PPE & Good & 17 & 60.7 \\
\hline
\end{tabular}

Table 3. Results of Observations of the Use of Ear Protection Equipment of Workers at PT. $\mathrm{X}$ in 2019

\begin{tabular}{lcc}
\hline $\begin{array}{c}\text { Observation } \\
\text { Results }\end{array}$ & Frequency & Percentage (\%) \\
\hline Obedient & 6 & 21.43 \\
Not obedient & 22 & 78.57 \\
\hline Total & 28 & 100 \\
\hline
\end{tabular}

Correlation between Work Period and the Compliance of Production Workers with the Use of Ear Protection Equipment

To find out the distribution of working period frequency, the data from the questionnaires were processed using the median cut, and the results are given in Table 4. From these data, it is known that the working period between the two groups of the animal feed production workers at PT. X has the same number of years of service; specifically, 14 production workers $(50 \%)$ have a working period of $>12$ years and 14 production workers $(50 \%)$ have a working period of $<12$ years. Meanwhile, the distribution of the frequency of compliance is given in Table 4. Data in Table 5 explain that as more workers, as many as $18(64.3 \%)$ animal feed production workers at PT. X, behave disobediently in the use of ear protection equipment. According to Geller (2001), factors that can influence the use of personal protective equipment (PPE) are the environment and the characteristics of people (age, work period, and education).

To find out the correlation of work period with the level of compliance of production animal feed workers, the data obtained from this study were

Table 4. Frequency Distribution of Years of Service of Workers at PT. X in 2019

\begin{tabular}{ccc}
\hline Years of service & Frequency & Percentage (\%) \\
\hline$<12$ & 14 & 50.0 \\
$>12$ & 14 & 50.0 \\
\hline
\end{tabular}

Table 5. Frequency Distribution of Compliance of Workers at PT. X 2019

\begin{tabular}{ccc}
\hline Compliance & Non-Compliance & Percentage (\%) \\
\hline Low & 18 & 64.3 \\
High & 10 & 35.7 \\
\hline
\end{tabular}

Table 6. Test Results of Relationship of Work Period with Compliance of Workers at PT. X in 2019

\begin{tabular}{|c|c|c|c|c|c|c|}
\hline \multirow{3}{*}{$\begin{array}{c}\text { W o r k } \\
\text { Periode }\end{array}$} & \multicolumn{4}{|c|}{ Compliance } & \multirow{3}{*}{$\begin{array}{l}\text { T o t a l } \\
\text { Workers }\end{array}$} & \multirow{3}{*}{$\%$} \\
\hline & \multicolumn{2}{|c|}{ Low } & \multicolumn{2}{|c|}{ High } & & \\
\hline & $\mathbf{n}$ & $\%$ & $\mathbf{n}$ & $\%$ & & \\
\hline $\begin{array}{c}<12 \\
\text { Years }\end{array}$ & 11 & 39.3 & 3 & 10.7 & 14 & 100 \\
\hline $\begin{array}{l}\geq 12 \\
\text { Years }\end{array}$ & 7 & 25.0 & 7 & 25.0 & 14 & 100 \\
\hline Total & 18 & 64.3 & 10 & 35.7 & 28 & 100 \\
\hline $\begin{array}{c}\text { Statistic } \\
\text { Test }\end{array}$ & \multicolumn{4}{|c|}{ Sig (0.115) } & & \\
\hline
\end{tabular}


processed using coefficient contingency where the results are tabulated in Table 6 . The results explain that more workers, as many as 11 people $(39.3 \%)$ of the group of production workers with a working period of $<12$ years are not compliance with wearing ear protection equipment when working in a production workspace. The results of the Sig value is 0.115 , which means that it is greater than the value of 0.05 , indicating that there is no relationship between the work period (more than 12 years or less than 12 years) with the compliance level with using ear protection equipment in animal feed production workers in PT. X.

\section{Correlation between Age and Production Workers' Compliance with the use of ear protection equipment}

By using the median cut, the age frequency distribution is obtained, and the results are given in Table 7. From these results, it is known that in animal feed production in PT. X there are 14 workers aged $>37$ years and 14 workers aged $<37$ years. It indicates that the company, when selecting workers, does not limit itself in the selection of young workers.

Using the coefficient contingency, the relationship between the age of production workers at PT. X and the level of compliance is obtained, and the results are presented in Table 8 . From these results, it is known that more workers, as many as 10 production workers $(35.7 \%$ out of $64.3 \%)$ with

Table 7. Age Frequency Distribution of Workers at PT. X in 2019

\begin{tabular}{ccc}
\hline Age & Frequency & Percentage (\%) \\
\hline$<37$ Year old & 14 & 50.0 \\
$>37$ Year old & 14 & 50.0 \\
\hline
\end{tabular}

Table 8. Test Results of the Relationship between Age and Compliance of Workers at PT. X in 2019

\begin{tabular}{|c|c|c|c|c|c|c|}
\hline \multirow{3}{*}{ Age } & \multicolumn{4}{|c|}{ Compliance } & \multirow{3}{*}{$\begin{array}{l}\text { Tot a l } \\
\text { Workers }\end{array}$} & \multirow{3}{*}{$\%$} \\
\hline & \multicolumn{2}{|c|}{ Low } & \multicolumn{2}{|c|}{ High } & & \\
\hline & n & $\%$ & $\mathbf{n}$ & $\%$ & & \\
\hline$<37$ Years & 10 & 35.7 & 4 & 14.3 & 14 & 100 \\
\hline$\geq 37$ Years & 8 & 28.6 & 6 & 21.4 & 14 & 100 \\
\hline Total & 18 & 64.3 & 10 & 35.7 & 28 & 100 \\
\hline $\begin{array}{l}\text { Statistic } \\
\text { Test }\end{array}$ & \multicolumn{4}{|c|}{$\operatorname{Sig}(0.430)$} & & \\
\hline
\end{tabular}

age group of $<37$ years old have a low level of compliance to wear ear protection equipment when working in the production workspace. The Sig value of 0.430 is greater than the value of $\alpha(0.05)$, which shows that there is no relationship between age and compliance with the use of ear protection equipment of animal feed production workers at PT. X.

From these results, it was found that more workers with the age of $<37$ years have low compliance compared to workers with the age of over 37 years. The results of the study also obtain a significant value more than the p-value of 0.430 , which means that there is no significant meaning of the relationship between age and compliance.

\section{DISCUSSION}

\section{Workers' Characteristics in PT. X in 2019}

According to research conducted by Farooqui et al. (2009), workers do not wear personal protective equipment (PPE) because they feel uncomfortable wearing it for 8 hours, the size does not fit them, they feel strange wearing personal protective equipment (PPE), and they not been given a training in how to use personal protective equipment (PPE). Moreover, there are no handling and attention the from supervisors.

The results are in line with a study by Wanjiku (2017), stating that some of the respondents do not wear personal protective equipment (PPE) because they have already had experience in carrying out their tasks without injury, so they feel they do not need to use personal protective equipment (PPE). This is also in line with the results of the study by Mashfufa, Kurnia, and Ashari (2019), suggesting that one of the reasons for not using PPE is because of uncomfortable feelings experienced by workers such as feeling uncomfortable, hot, bulky, or disturbed.

\section{The Correlation between Work Period and the Compliance of Production Workers with the Use of Ear Protection Equipment}

The results of this study are in line with the results of research conducted by Sudarmo, Helmi and Marlinae (2017) suggesting that work period is not related to the compliance with the behavior of using personal protective equipment (PPE) because work period is not the main factor, yet the compliance level is likely due to one's education, level of knowledge, supervision, and motivation. 
Puji, Kurniawan and Jayanti (2017) also explain that the absence of a relationship between work period and the use of personal protective equipment (PPE) is due to the boredom factor, caused by prolonged work periods and the monotonous, repeated works, eventually causing burnout. According to Hasriani (2009), there is no relationship between the work period of workers in the radiation room and the behavior of the use of personal protective equipment (PPE) because work period is not one of the causes of non-compliance behavior in using personal protective equipment (PPE). Hidayat, Suryanto and Ulfah's (2013) research also explains that there is no relationship between the work period and compliance behavior with the use of masks because the longer the work period of a person, the higher the chance for older workers to negatively influence new workers (one example in this industry is not wearing a mask when working).

However, the resultsof this study are not in line with the study conducted by Nizar, Tuna, and Sumaningrum (2016) which states that years of service could be related to the compliance with the use of personal protective equipment (PPE). The longer the work period, the higher the level of knowledge because workers get a lot of experience. Notoatmodjo (2007) also states that the longer work experience the workers have, the the more skillful and easier the workers are in understanding the task. Thus, they can improve their performance and get a better experience in the use of personal protective equipment (PPE). Conversely, the shorter the work period, the less experience gained. Likewise, according to Wibowo, Suryani, and Sayono (2013), work period can be related to compliance because the experience is a combination of knowledge and behavior; the length of work is identical to one's experience, so the longer they work, the more knowledge and experience they have.

\section{The Correlation between Age and the Compliance of Production Workers with the Use of Ear Protection Equipment}

The results of this study are not in line with previous research conducted by Kurniawan, Setyaningsih, and Wahyuni (2017) which states that there is a relationship between age and compliance behavior in using ear protection equipment because younger workers are more obedient and more comfortable in following the rules or procedures. According to Notoatmodjo (2007), the older the people are, and the higher level of maturity they have in the way they work and think. Moreover, Apriluana, Khairiyati and Setyaningrum (2016) suggest a relationship between age and the level of compliance with the use of personal protective equipment (PPE) because the age of 20-25 years old is the phase starting when someone enters the adulthood and the world of work, and looks for social relationships. Meanwhile, the age of $>$ 26 years old becomes more critical because in that stage, people become more stable and mature enough from the experiences gained.

The results of this study are also in line with the results of research conducted by Sari, Wiediartini, and Rachman (2015) suggesting that there is no relationship between age and the level of compliance in the use of personal protective equipment (PPE). The results of this study are also supported by another research conducted by Sari (2014), which states that there is no relationship between age and the level of compliance in using personal protective equipment (PPE) because there are still many workers in the field who are not compliant with PPE. According to Hidayanti and Kasman (2018), having a mature age and long working period do not guarantee that workers are obedient in using PPE. Another research of Damalas and Abdollahzadeh (2016) also explains that there is no relationship between age and compliance behavior to use PPE because older age can have adverse effects for workers such as burnout and laziness to wear personal protective equipment (PPE) compared to younger workers. This is further supported by the results of research conducted by Chahak, et al. (2018) stating that there is no relationship between age and years of service on the level of compliance with the use of PPE. Likewise, previous research done by Agustina (2015) also states that there is no relationship between the age of workers (younger or older age groups) with compliance behavior of using personal protective equipment (PPE).

According to Lombardi (2009), older workers mostly tend to wear personal protective equipment (PPE) different from the behaviour of younger workers due to a lack of experience and knowledge about personal protective equipment (PPE). Holte and Kjestveit (2012) further add thatworkers aged $<30$ years old are more likely to have an accident because they do not use personal protective equipment (PPE). However, according to Madyanti (2012), older workers are relatively limited in physical abilities compared to younger workers. Based on Kalasuat (2019), the obedience 
of workers in using personal protective equipment (PPE) is not parallel to age levels, either older or younger age groups, because as time goes by the physical and mental development of individuals will experience changes, depending on the type of work they handle.

\section{CONCLUSION}

From the description and analyses presented above, it can be concluded that the results of this study are as follows: the number of workers whose working period $<12$ years is $50 \%$, and the number of workers aged $<37$ years is also $50 \%$.

Moreover, it is also found that there is no relationship between the work period $(\geq 12$ years or $<12$ years) and the compliance with the use of ear protection equipment among production workers in the animal feed industry in PT. X. Specifically, $39.3 \%$ out of $64.3 \%$ of workers whodo not comply with the ear protection equipment regulation have a working period of $<12$ years; this is indicated by the value of $\mathrm{Sig}=0.115$, which is greater than 0.05 , which means that there is no relationship between work period and the compliance with the use of ear protection equipment. Furthermore, there is no effect of age ( $\geq 37$ years or $<37$ years) on the compliance with the use of ear protection equipment among production workers in the animal feed industry at PT. X. Specifically, $35.7 \%$ out of $64.3 \%$ of workers who are not compliant with the use of ear protection equipment are in the age of $<37$ years; this result is supported by the Sig value of 0.430 , which is greater than 0.05 , which means that there is no relationship between age and the compliance with ear protection equipmentSome reasons for the disobedience of animal feed production workers at PT. X tothe use of ear protection equipment are discomfort, a lack of supervision, and a lack of motivation.

\section{ACKNOWLEDGMENTS}

The author would like to thank Airlangga University, Surabaya. The author is also particularly grateful forthe respondents and the research site.

\section{REFERENCES}

Agustina, D. E. (2015) Perilaku Pemakaian Alat Pelindung Diri (APD) (Studi di Bagian Coal and Ash Handling PT. PJB UBJ O\&M PLTU Paiton
9), Research Articles. Jember: Faculty of Public Health Universitas Jember.

Apriluana, G., Khairiyati, L. and Setyaningrum, R. (2016) 'Hubungan Antara Usia, Jenis Kelamin, Lama Kerja, Pengetahuan, Sikap dan Ketersediaan Alat Pelindung Diri (APD) Dengan Perilaku Penggunaan APD Pada Tenaga Kesehatan', Jurnal Publikasi Kesehatan Masyarakat Indonesia, 3(3), pp. 82-87.

Azwar, S. (2005) 'Signifikan atau Sangat Signifikan', Buletin Psikologi, 13(1), pp. 38-44.

Chahak, A. F., et al. (2018) 'Factors Affecting the Use of Respiratory Protection Devices Based on the Health Belief Model in Welders', Archives of Occupational Health, 2(1), pp. 70-74.

Damalas, C. A. and Abdollahzadeh, G. (2016) 'Farmers' use of Personal Protective Equipment during Handling of Plant Protection Products: Determinants of Implementation', Science of the Total Environment. Elsevi, 571 (November), pp. 730-736.

Farooqui, R. U. et al. (2009) 'Addressing the Issue of Compliance with Personal Protective Equipment on Construction Worksites : A Workers 'Perspective', International Proceedings of the 45th Annual Conference, Associated Schools of Construction, 2005(2005), pp. 1-10.

Geller, E. . (2001) The Psychology of Safety Handbook. New York: Lewis Publisher.

Hasriani, R. D. (2009) 'Faktor-Faktor yang Berhubungan dengan Perilaku Keselamatan dan Kesehatan Kerja (K3) Pada Perawat Rumah Sakit Paru Di Salatiga'. Undergraduate Thesis. Semarang: Faculty of Public Health Universitas Diponegoro.

Hidayat, F., Suryanto and Ulfah, N. (2013) 'Faktorfaktor yang Berhubungan dengan Perilaku Pemakaian Masker pada Pekerja Kontraktor di Packing House P.10 PT. Indocement Tunggal Prakarsa Tbk. Cirebon', Kesmasindo, 6(2), pp. 125-134.

Hidayanti, R., Kasman, and Jannah, R. (2018) 'Faktor-Faktor yang Berhubungan dengan Penggunaan Alat Pelindung Diri pada Petani Penggunaan Pestisida', PROMOTIF: Jurnal Kesehatan Masyarakat, 8(1), pp. 11-17.

Holte, K. A. and Kjestveit, K. (2012) 'Young workers in the construction industry and initial OSH-training when entering work-life', Work, 41(SUPPL.1), pp. 4137-4141.

Ibrahim, H., Basri, S. and Hamzah, Z. (2016) 'Faktor - Faktor Yang Berhubungan Dengan 
Keluhan Gangguan Pendengaran Pada Tenaga Kerja Bagian Produksi PT. Japfa Comfeed', AlSihah : Public Health Science Journal, 8(2), pp. 121-129.

Kalasuat, J. et al. (2019) 'Analysis of use of protective equipment (PPE) in employees PT Conch Cement Manokwari District West Papua', Galore International Journal of Health Sciences and Research, 4(1), pp. 62-71.

Kurniawan, W., Setyaningsih, Y. and Wahyuni, I. (2017) 'Hubungan Faktor Karakteristik Pekerja, Safety Morning Talk (SMT) Dan Housekeeping Dengan Kejadian Minor Injury Pada Pekerja Di Proyek Pembangunan Gedung Kantor Pt. X Jakarta', Jurnal Kesehatan Masyarakat Universitas Diponegoro, 5(3), pp. 323-331.

Lombardi, D. A. et al. (2009) 'Factors influencing worker use of personal protective eyewear', Accident Analysis and Prevention, 41(4), pp. 755-762.

Madyanti, D. R. (2012) Factors that Influence the Use of Personal Protective Equipment (PPE) in Midwives when Performing Labor Assistance in Bengkilis Hospital in 2012. Undergraduate Thesis. Depok: Faculty of Publich Health Universitas Indonesia.

Martino, P., Rinawati, D. I. and Rumita, R. (2015) 'Analisis Identifikasi Bahaya Kecelakaan Kerja Menggunakan Job Safety Analysis (JSA) Dengan Pendekatan Hazard Identification, Risk Assessment And Risk Control (HIRARC) di PT. Charoen Pokphand Indonesia- Semarang', Industrial Engineering Online Journal, 4(2), pp.1-9.

Mashfufa, E. W., Kurnia, A. D. and Ashari, F. (2019) 'Relationship of Knowledge and Compliance Using Personal Protective Equipment on Construction Workers in PT X Pasuruan Regency', Journal of Chemical Information and Modeling, 53(9), pp. 1689-1699.

Ministry of Manpower of the Republic of Indonesia (2018) No. 5 tahun 2018 tentang Keselamatan dan Kesehatan Kerja Lingkungan Kerja, Jakarta: Ministry of Manpower of the Republic of Indonesia.

Ministry of Manpower and Transmigration (2010) Nomer PER.08/MEN/VII/2010 Tentang Alat Pelindung Diri. Jakarta: Ministry of Manpower and Transmigration .

Nizar, M. F., Tuna, H. and Sumaningrum, N. D. (2016) 'Hubungan Karakteristik Pekerja Dengan Kepatuhan Dalam Pemakaian Alat Pelindung
Diri (APD) Pada Petugas Laboratorium Klinik di Rumah Sakit Baptis Kota Kediri', Preventia : The Indonesian Journal of Public Health, 1(1), pp. 1-6.

Notoatmodjo, S. (2007) Promosi Kesehatan dan Ilmu Perilaku. Jakarta: Rineka cipta.

OSHA (2002) 'Job Hazard Analysis', Accident Prevention and Osha Compliance, pp. 25-29.

Puji, A. D., Kurniawan, B. and Jayanti, S. (2017) 'Faktor Faktor Yang Berhubungan Dengan Kepatuhan Penggunaan Alat Pelindung Diri Pada Pekerja Rekanan (PT. X) Di PT Indonesia Power Up Semarang', Jurnal Kesehatan Masyarakat (e-Journal), 5(5), pp. 20-31.

Rahman, Z. F. and Tualeka, A. R. (2020) 'Risk Assessment, Risk Management, and Risk Communication in the Carpet Industry : PT .' $\mathrm{X}$ ' Pandaan . East Jawa', Indian Journal of Forensic Medicine \& Toxicology, 14(1), pp. 385-389.

Sari, N. P., (2014) Pengaruh Iklim Kerja Panas terhadap Dehidrasi dan Kelelahan pada Tenaga Kerja Bagian Boiler di PT Albasiah Sejahtera Mandiri Kabupaten Semarang. Undergraduate Thesis. Surakarta: Faculty of Helath Science Universitas Muhammadiyah Surakarta.

Sari, R. N., Wiediartini, and Rachman, F. (2015) 'Analisis Pengaruh Karakteristik Individu dan Kepribadian Terhadap Tingkat Kedisiplinan Penggunaan APD di PT . Petrowidada Gresik', Proceeding 1st Conference on Safety Engineering and Its Application, pp. 7-12.

Sudarmo, S., Helmi, Z. N. and Marlinae, L. (2017) 'Faktor Yang Mempengaruhi Perilaku Terhadap Kepatuhan Penggunaan Alat Pelindung Diri (APD) Untuk Pencegahan Penyakit Akibat Kerja', Jurnal Berkala Kesehatan, 1(2), pp. 88-95.

Tarwaka (2004) Ergonomi untuk Keselamatan, Kesehatan Kerja dan Produktivitas. Surakarta: Harapan Press.

Wanjiku, M. F. (2017) Factors Influencing Use of Personal Protective Equipment (PPE's) by Motor Vehicle Repair Workers in Kigandaini, Thika. Thesis. Nairobi: Institute ofor Development Studies University of Nairobi..

Wibowo, A., Suryani, M. and Sayono (2013) 'Hubungan Karakteristik Perawat Dengan Penggunaan Sarung Tangan Pada Tindakan Invasif di Ruang Rawat Inap RSUD Dr. H. Soewondo Kendal', Jurnal Ilmu Keperawatan dan Kebidanan, 1(4), pp. 1-9. 